\title{
Computers in Health Care
}

\section{Kathryn J. Hannah Marion J. Ball}

Series Editors

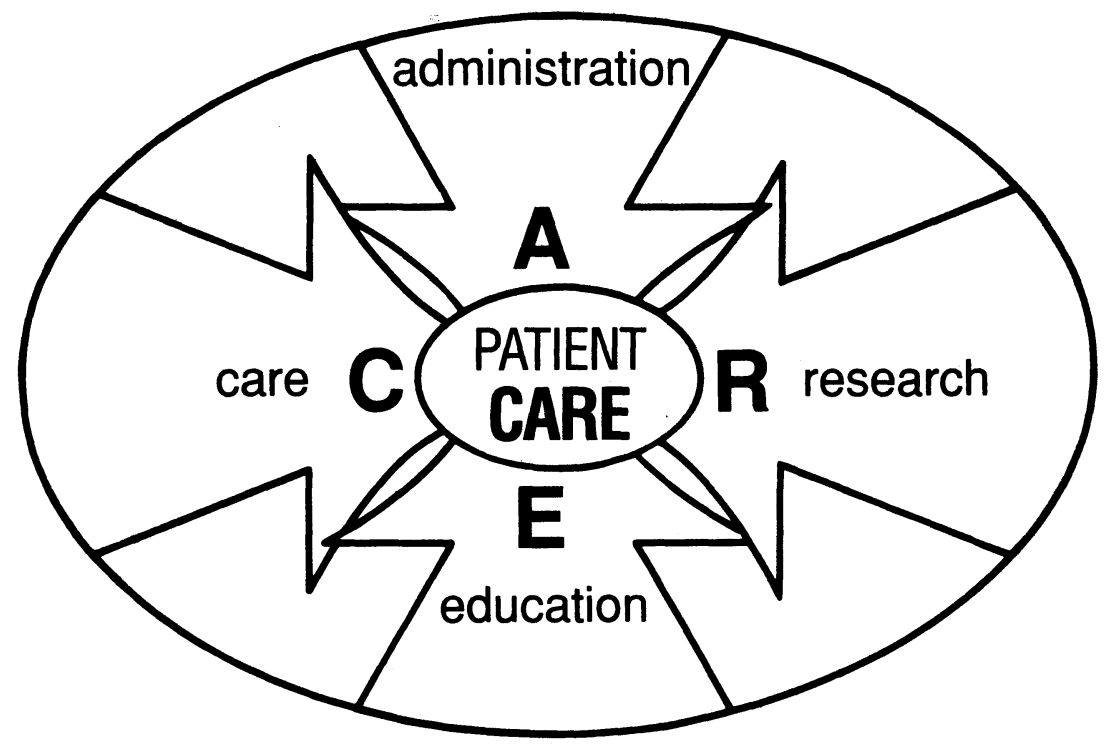


Computers in Health Care

Series Editors:

Kathryn J. Hannah Marion J. Ball

Nursing Informatics

Where Caring and Technology Meet

M.J. Ball, K.J. Hannah, U. Gerdin Jelger, and H. Peterson

Healthcare Information Management Systems

A Practical Guide

M.J. Ball, J.V. Douglas, R.I. O'Desky, and J.W. Albright

Knowledge Coupling

New Premises and New Tools for Medical Care and Education

Lawrence L. Weed

Dental Informatics

Integrating Technology into the Dental Environment

Louis M. Abbey and John Zimmerman

Aspects of the Computer-based Patient Record

Marion J. Ball and Morris F. Collen 


\section{Marion J. Ball Morris F. Collen Editors}

\section{Aspects of the \\ Computer-based Patient Record}

With 18 Illustrations

Springer Science+Business Media, LLC 
Marion J. Ball, Ed.D.

Associate Vice President

Information Resources

University of Maryland at Baltimore

610 West Lombard St.

Baltimore, MD 21201, USA
Morris F. Collen

Director Emeritus

Kaiser Permanente Medical Care Program

3451 Piedmont Ave.

Oakland, CA 94611, USA

Cover illustration: The illumination on the cover is from a medieval manuscript found in the National Library of Medicine collection. This manuscript, by Hunain Ibn Ishaq, El Abadiis, is from the 13th century. This is the oldest book in the National Library of Medicine's collection.

Library of Congress Cataloging-in-Publication Data

Aspects of the computer-based patient record / Marion J. Ball, Morris

F. Collen, editors.

p. cm. " (Computers in health care)

Includes bibliographical references and index.

ISBN 978-1-4757-3875-9 ISBN 978-1-4757-3873-5 (eBook)

DOI 10.1007/978-1-4757-3873-5

1. Medical records-Data processing. I. Ball, Marion J.

II. Collen, Morris F. (Morris Frank), 1913- . . II. Series:

Computers in health care (New York, N.Y.)

R864.A87 1992

$651.5^{\prime} 04261^{\prime} 0285^{\prime \prime} \mathrm{dc} 20$

$91-33021$

Printed on acid-free paper.

(C) 1992 Springer Science+Business Media New York

Originally published by Springer-Verlag New York Inc. in 1992.

Softcover reprint of the hardcover 1st edition 1992

All rights reserved. This work may not be translated or copied in whole or in part without the written permission of the publisher ( Springer Science+Business Media, LLC), except for brief excerpts in connection with reviews or scholarly analysis. Use in connection with any form of information storage and retrieval electronic adaptation, computer software, or by similar or dissimilar methodology now known or hereafter developed is forbidden.

The use of general descriptive names, trade names, trademarks, etc., in this publication, even if the former are not especially identified, is not to be taken as a sign that such names, as understood by the Trade Marks and Merchandise Marks Act, may accordingly be used freely by anyone.

While the advice and information in this book is believed to be true and accurate at the date of going to press, neither the authors nor the editors nor the publisher can accept any legal responsibility for any errors or omissions that may be made. The publisher makes no warranty, express or implied, with respect to the material contained herein.

Production managed by Christin R. Ciresi; Manufacturing supervised by Jacqui Ashri.

Typeset by Princeton Editorial Associates, Princeton, NJ. 
The book is dedicated to Judith Vetter Douglas in grateful recognition of her diligence and devotion to making the series entitled "Computers in Health Care" the success it is today. Her dedication to working with the contributing authors has earned her the respect of the international informatics field. It is individuals such as Judith Vetter Douglas who make it possible to continually produce such high quality manuscripts. It is with grateful appreciation that I wish to acknowledge the continuing invaluable support that I receive from Judith.

Marion J. Ball, Ed.D. 


\title{
Foreword
}

\author{
Don E. Detmer
}

Health care is experiencing an information explosion in the form of knowledge and data. Medical knowledge is increasing virtually on a daily basis. The questions that we are asking about the appropriateness and effectiveness of clinical treatments will provide even more information for practitioners to consider in providing patient care. We have more data and more complex data to track for patients over the course of their lives.

At the same time as the quantity and complexity of patient data are increasing, there is greater demand for data to support activities other than direct patient care. Health services researchers, managers of provider institutions, third party payers, and others seek access to patient care to evaluate, manage, and reimburse health care services. We do not, however, have a means of managing all of this knowledge and these data, and this lack of information management capability is adding stress to the already burdened U.S. health care system.

In April 1991, the Institute of Medicine (IOM) of the National Academy of Sciences completed an 18-month study on improving patient records in response to the need for better information management and increasing technological advances. The study was conducted by a multidisciplinary committee of experts and was funded by a diverse set of public and private sector organizations. The study committee was charged to do the following:

- Examine the current state of medical record systems

- Identify impediments to the development and use of improved record systems

- Identify ways to overcome impediments to improved medical records

- Develop a research agenda to advance medical record systems

- Recommend policies or other strategies to achieve these improvements

The conclusions and recommendations of this study are described in The Computer-Based Patient Record: An Essential Technology for Health Care (National Academy Press 1991).

As a means of accomplishing its work and achieving broader representation in the study process, the committee established subcommittees to explore three major dimensions of patient record improvement. Donald Berwick, M.D., and Carmi 
Margolis, M.D., chaired the Users and Uses Subcommittee, which was charged with identifying the users of patient records, the uses of patient records, and the functional characteristics of records that would meet user needs. The Technology Subcommittee was chaired by Morris Collen, M.D., and Marion J. Ball, Ed.D., the editors of this volume. Their task was to examine the current state of technology available to support patient records and to identify the areas where patient record technology could not yet meet the needs of users. The third subcommittee, Strategy and Implementation, was chaired by Edward Shortliffe, M.D., and Paul Tang, M.D. This subcommittee was charged with defining a strategy to overcome the technical, logistical, sociopolitical, and financial impediments to timely phased improvements in the patient record.

The detailed work of the three subcommittees contributed significantly to the committee's deliberations, as did several background papers that were prepared on specific issues for the committee. One of the challenges faced by the committee in preparing its report was to provide a thorough yet concise description of what patient records should be and why computer-based patient records are essential to health care. As a result, all of the detailed papers that were considered by the committee were not included in its final report. This volume complements the study committee's report by presenting the subcommittee reports, as well as discussion papers and background papers. The volume thus provides a valuable service by enabling us to share those contributions with a broader audience.

I offer a brief discussion of the study committee's recommendations below to provide a framework within which the contents of this volume can be better understood. For a more detailed explanation of the recommendations and the rationale underlying the recommendations, I refer you to the committee's report.

The first and primary recommendation of the committee is that health care practitioners should adopt the computer-based patient record (CPR) as the standard for medical and all other records related to patient care. The future patient record envisioned by the IOM committee is not simply a digitized version of the current paper record; rather, it provides broader functions to practitioners, is used actively by practitioners in the delivery of care, and serves as a resource in the evaluation and management of patient care.

The committee developed a very specific definition of what a CPR is and identified basic attributes of CPRs and CPR systems. CPRs should contain a problem list, health status and functional level, and clinician rationale for patient care decisions. They should be able to be linked with other clinical records to provide a longitudinal patient record. CPR systems must protect patient confidentiality. They must also provide convenient access to authorized users at all times, support direct data entry by practitioners, and allow custom-tailored views of the data. CPR systems should be able to be linked to knowledge, literature, and bibliographic databases. They must be flexible and expandable to support the evolving needs of users. Such CPRs and CPR systems will assist the process of clinical problem solving and enable practitioners and institutions to evaluate and manage the quality and costs of care.

The committee concluded that the CPR is an essential technology for health care 
for three key reasons. First, the uses and demands of patient data are increasing. Second, the increasing complexity of treatment, the growing numbers of elderly patients with chronic illnesses, and a continually mobile population are generating more data to be tracked and greater difficulty in tracking them. Third, achieving the goals of improving the quality and managing the costs of health care requires improved information management capabilities.

The committee also concluded that widespread implementation of CPRs can be achieved within a relatively short time frame (i.e., 10 years) if adequate resources and coordination are devoted to the effort. The committee based this conclusion on the increasing prevalence of computers in everyday life and the advances achieved to date in computer and networking technologies. Thus, the committee's second recommendation is that the public and private sectors should join in establishing an institute to promote and facilitate the development and implementation of CPRs. Such an institute would be involved in a range of activities including standards setting, demonstration projects, and educational programs on CPRs. The committee proposed an organizational structure for such an institute in its report, but emphasized that the means used to achieve widespread implementation of CPRs are less important than achieving that end.

The committee's four remaining recommendations identify ways to overcome specific barriers to CPR development and implementation. The committee recognized that, although a great deal of progress has been made in computer technology, more work is needed for CPRs to meet the functional requirements of users. Thus, the committee recommended that both the public and private sectors expand support for CPR research and development, and the committee provided an agenda to guide that research. The committee emphasized the need for and importance of both data and security standards in its recommendation that the CPR institute should promulgate such standards.

Legal issues surrounding CPRs need attention. Many states do not recognize computer-based records as a legitimate means of storing patient data. There is no consistency among state laws on patient record form, access to records, and protection of patient records. Thus, the committee recommended that the CPR institute conduct a review of state and federal laws and regulations and propose model legislation and regulations to facilitate implementation of the CPR. Such a review should include an examination of unnecessary regulations that add waste and redundancy to patient records so that future records can be streamlined.

Obviously, there are costs associated with developing, acquiring, and operating CPR systems. The committee believed that those costs should be shared by those who benefit from the CPR and recommended that such costs be factored into reimbursement levels or payment schedules of both public and private sector third party payers. Users of secondary databases created from CPRs should also support the costs of creating such databases.

Success in CPR implementation requires that users have adequate computer skills and that there be more individuals with training in medical informatics to support the development of CPRs. The IOM committee recommended that health care professional schools and organizations enhance their educational programs 
for students and practitioners. This educational effort should address the use of computers, CPRs, and CPR systems for patient care, education, and research.

It is interesting to note that when the committee began its deliberations, we identified two possible outcomes that might result from our study. First, it was possible that little would result from our effort since the concept of linking computers and patient records was not a new one and progress in that area had been slow. Second, it was possible that the conditions were right for us to make a contribution toward advancing computer-based patient records by making a strong case for the value of such records and identifying the potential to achieve them. All of the committee completed the project with a great deal of optimism and enthusiasm for a future vision of computer-based patient records - a vision that we strongly believe can become a reality.

The committee concluded its work with the hope that its report would generate increased commitment to and resources for patient record development. On the day that the report was released, my testimony before the Health Subcommittee of the Ways and Means Committee in the U.S. House of Representatives on behalf of the IOM study committee received a very receptive hearing. Congressional interest in this issue is evident in the form of H.R. 1565 (102d Congress, first session, 1991) - which would provide a strong impetus to achieving our CPR agenda.

Within a week of the report release, we also had the opportunity to share the results of the study directly with the American Medical Association Council on Scientific Affairs, the American Medical Record Association, and the New England Healthcare Assembly. Additional briefings and presentations have been given to a variety of groups since then.

At the time of this writing, it is impossible to judge how successful the committee and its subcommittees will prove to be in advancing CPR development and implementation and, in so doing, influencing the shape of the health care system of tomorrow. We certainly were successful in learning from one another and we share a common sense of what the future can hold.

I am confident that you will both enjoy and benefit from the various contributions in this volume. The IOM patient record study brought together people with the greatest experience and interest in this subject; more than 200 individuals from across the nation were involved with this effort. The project proved to be consistently challenging, illuminating, and entertaining.

A final word of appreciation is offered to all of the committee members, subcommittee members, and subcommittee advisors who contributed to the study. As chair of the study committee, I am personally grateful to the individuals whose work appears in this volume for their contributions not only to the study but also to my own understanding of the issues surrounding computer-based patient records. I would also like to acknowledge the study staff, Elaine Steen and Richard Dick, for their continuing expertise and efforts to bring the report to a timely and successful conclusion. Cliff Goodman deserves mention for helping start the study, as do Dick Rettig, Queta Bond, and Sam Thier. Completion of the study also is a result of the efforts of Kathy Lohr and Karl Yordy. 


\section{Preface}

The increasing need of patients for better access to good quality care, the great mobility of people in this nation and their quest for care from a variety of health care professionals, the need for clinicians to have online decision making support and readily transferrable patient records, the continuing increase in the costs of medical care with frustrated health policy makers searching for adequate databases to better analyze complex health care delivery problems, the need for faster and lower cost electronic claims reimbursement processes all have made it very clear that it has become essential-indeed, have made it imperative - that throughout this country the current obsolescent paper-based medical records must be replaced as soon as possible by computer-based patient records (CPRs).

Medical informatics-the application of computers and communications to medicine - has sufficiently advanced to permit a realistic vision of a new and improved patient record. Informatics technology will not only replace the traditional documentation functions of paper based records, but can provide through computer-based patient records a new dimension of support for patient care, administration, policy making, and research.

In recognition of this high priority need, the Institute of Medicine (IOM) formed the Committee on Improving the Patient Record. The result was the publication of The Computer-Based Patient Record: An Essential Technology for Health Care, edited by Richard S. Dick and Elaine B. Steen, and published by the National Academy Press, Washington, D.C., in 1991. As stated Dick and Steen state in the preface of their book,

This report advocates the prompt development and implementation of computerbased patient records (CPRs). Put simply, this Institute of Medicine committee believes that CPRs and CPR systems have a unique potential to improve the care of both individual patients and populations and, concurrently, to reduce waste through continuous quality improvement.

The enthusiastic support of this IOM project by members of its committee and subcommittees resulted in the preparation of such a large number of worthy supporting papers that it was not possible to include them in the IOM publication. Accordingly, the IOM authorized the editors of this book to publish separately some 
xii Preface

papers that fit appropriately into this more technology-oriented book. We hope that this collection of papers will be useful as a supplement to the IOM report for those who want to read more of the detailed texts that were available to the writers of that report.

Marion J. Ball

Morris F. Collen 


\section{Acknowledgments}

The authorization by the Institute of Medicine (IOM) for the separate publication of these papers, arranged by Kathleen N. Lohr, is gratefully acknowledged. We are indebted to the subcommittee members and the many authors of these papers for all the time they volunteered to prepare the manuscripts and for their willingness to have their papers included in this book.

The chairs and assistant chairs of the three subcommittees, responsible for the preparation of these papers, were as follows:

Users and Uses Subcommittee, Donald M. Berwick, Chair, and Carmi Margolis, Assistant Chair

Technology Subcommittee, Morris F. Collen, Chair, and Marion J. Ball, Assistant Chair

Strategy and Implementation Subcommittee, Edward H. Shortliffe, Chair, and Paul C. Tang, Assistant Chair

We acknowledge the help of Richard S. Dick, IOM Study Director, and Elaine B. Steen, IOM Staff Officer, in collecting and providing copies of the papers included in this book. We thank the Institute of Medicine for providing the following list of professionals who contributed their time and energy to the Committee to Improve the Patient Record and its deliberations:

Denise L. Allec, Ray Aller, Terry Alley, Stuart H. Altman, Margret Amatayakul, Kathleen G. Andreoli, James N. Applebaum, Howard L. Bailit, Landon Bain, Ruth E. Baldwin, John Ball, Marion J. Ball, Steven Bandian, G. Octo Barnett, William Barrick, Kenneth Bartholemew, Paul B. Batalden, Eric Batson, J. Robert Beck, Donald M. Berwick, Brian Biles, Jay C. Bisgard, Gordon C. Black, Jeff Blair, E.F. Blasser, Merryl Bloomrosen, M. A. Bobenrieth, Sal Bognanni, Enriqueta Bond, A. Peter Bouxsein, Vincent M. Brannigan, William Bria, Karen Brigham, Karen Berg Brigham, Judith Brinkerhoff, Melanie Brodnik, Robert H. Brook, Maria T. Brooks, Michael H. Brown, Lynda S. Browne, Michael Buckley, William H. Buckley, John M. Burns, Henry N. Camp, Paul C. Carpenter, Eugene Santa Cattarina, Jean Chenoweth, Arnold Cherdak, Stephan E. Chertoff, Paul D. Clayton, Clifton R. Cleaveland, J. Jarrett Clinton, Jerry Cohen, Morris F. Collen, Michael Congleton, 
Donald P. Conway, Dick Corley, Jerome R. Cox, Jr., Harold D. Cross, Glenn Crowe, Clayton Curtis, Frank Davidoff, Allyson Ross Davies, Nicholas E. Davies, Holly V. Dawkins, Jim Demetriades, Michael Denny, Don E. Detmer, Richard S. Dick, Kenneth Dickie, Susan Dowell, Paul Dragsten, Paul M. Ellwood, Mark H. Epstein, Paul Y. Ertel, Robert J. Esterhay, Jr., Betty Falter, John Farrer, Daniel D. Federman, William R. Felts, John H. Ferguson, David M. Ferris, Rita Finnegan, Craig Fisher, J. Michael Fitzmaurice, Suzanne W. Fletcher, Nathaniel Folster, Sandra Forquer, Arden W. Forrey, John L. Foy, Richard B. Friedman, Barbara Fuller, Hugh S. Fulmer, Elmer R. Gabrieli, John S. Gage, Elizabeth M. Gallup, Wilbur H. Gantz, Donna Ganzer, Elizabeth Gardner, Andrew Garling, Leland E. Garrett, Jr., Gwen Gengler, Paul M. Gertman, Diane Gianelli, Ann C. Giese, Paul Ginsburg, John P. Glaser, Jerome C. Goldstein, Paul F. Griner, Susan Grobe, Nancy Guadagno, David H. Gustafson, Glenn M. Hackbarth, Ethan Halm, William E. Hammond, Kathryn Hannah, Jack Harrington, Randall Harris, Gary Hassalblad, Robert R. Hausam, Alice Hersch, Guy Hess, Barry R. Hieb, Thomas Higgins, Ane F. Higley, Mary M. Hill, John Holbrook, Benjamin L. Holmes, Gary Hong, Susan D. Horn, Robert Hoyer, Michael R. Huber, G.M.K. Hughes, Robert G. Hughes, Betsy L. Humphreys, Robert W. Hungate, James C. Hunt, Karen Hunt, Karen Ignani, John L. Indermuehle, Stephen F. Jencks, Richard Johannes, Judith Jones, Judy Miller Jones, DeSoto Jordan, Joseph Jorgens, Evanson Joseph, Linda S. Joseph, Charles N. Kahn III, Douglas B. Kamerow, Arthur Kaufman, Alan C. Kay, Hazel K. Keimowitz, Samuel H. Kiehl, Steven King, Larry Kingsland, Deborah Kohn, Ralph Korpman, Henry J. Krakauer, Hans Kuttner, Ann LaBelle, Richard Landen, John Landon, Maria Elena Lara, Richard Leadem, Pepper Leeper, Allan H. Levy, Thomas Lewis, Donald A.B. Lindberg, Orley Lindgren, Kathy Lohr, Gwilyn S. Lodwick, Harold S. Luft, Alice Lusk, Walter B. Maher, Jane Majcher, Sandra A. Mamrak, Carmi Margolis, Albert Martin, William Mason, Katie Massuckelli, R. Masys, Patrick Mattingly, Michael G. Mayberry, Leah Mazade, Kathleen A. McCormick, Thomas F. McCoy, Clement J. McDonald, James McDonald, Mary McHugh, Sean McLinden, Barbara J. McNeil, Bruce McPherson, Regina McPhillips, Paul Mehne, Kenneth L. Melmon, Albert I. Mendeloff, Enrique Mendez, Jr., Marianne Miller, Randy Miller, Charles E. Molnar, John Morgan, Thomas Q. Morris, Thomas Morrison, Jennysue D. Mott, Gretchen Murphy, Jack Myers, Richard Nani, John Napoli, Nicholas Negroponte, Alan R. Nelson, John C. Nemiah, Joseph P. Newhouse, Donald R. Newkirk, Jeremy Nobel, Lowell Noble, Nanci Noie, John Norris, Deborah G. Novak, Ellie N. Oakley, Karen J. O'Connor, Patrick O'Keeffe, Dennis O'Leary, Helmuth F. Orthner, Judy Ozbolt, Walter Parrin, Ramesh Patil, Robert Patricelli, Stanley B. Peck, H. Ross Perot, Gilles Pigeon, Jesse M. Polansky, Samuel Porter, Fred Prior, David B. Pryor, T. Allan Pryor, Robert B. Ramsey, James Reinertsen, Stanley Reiser, Kathy Renz, Peter Rheinstein, Joe Ribatto, Del Richmond, James S. Roberts, Fredrick Robins, Noralou P. Roos, William L. Roper, Harold P. Roth, John Rother, Virginia K. Saba, Damaian M. Saccocio, John Salley, Jerome H. Saltzer, Cecil O. Samuelson, Ralph Schaffarzick, Donald Schiffman, Peter Schipma, Robert S. Schlotman, Martin L. Schneider, Paul Schoemaker, Stephen C. Schoenbaum, Dale N. Schumacher, 
Harvey Schwartz, Michael Scotti, Cary Sennett, Gerard E. Seufert, Jr., J. Christopher Shank, Roger H. Shannon, Richard S. Sharpe, Barclay M. Shepard, Gregory I. Shorr, Edward H. Shortliffe, Eliot Siegel, John Silva, Herbert Simon, Dee Simons, John D. Simpkins, Roy L. Simpson, Warner V. Slack, Scott Slivka, Dale P. Smith, Peter Spitzer, Eugene A. Stead, Jr., William W. Stead, Elaine B. Steen, Donald M. Steinwachs, Michael Stoto, MaryAnn Stump, Richard Suddick, James Summe, John P. Sulima, Paul C. Tang, Jack R. Taub, Zachary Taylor, Francis A. Testa, Samuel Thier, B.G. Thompson, Paul Tibbits, Sheldon Tobin, Elaine Ullian, Carlos Vallbona, Elaine Viseltear, Peggy Vollstedt, Adele Waller, Peter Walton, John E. Ware, Jr., Homer R. Warner, Lawrence L. Weed, Kathi Weis, Leonard Weiss, Norman W. Weissman, Rebecca J. Welty, Elizabeth West, Sue West, Jeff White, John Whiteman, Gio Wiederhold, Gail R. Wilensky, Albert P. Williams, Willis H. Williams, Mary Joan Wogan, Steven H. Woolf, Alfred Yankauer, Eli Yecheskel, Karl Yordy, Donald Young, Steven Zatz.

We also thank Joann Sommers, who contacted the authors of the papers included in this volume; Charles Baker, a college student who spent a good part of his summer retyping manuscripts not available in electronic form; and Judith Douglas, who oversaw the editorial process and helped bring this book to print. 


\section{Contents}

Foreword Don E. Detmer vii

Preface $x i$

Acknowledgments xiii

Contributors xxi

\section{Section 1 User Needs for Computer-based Patient Records} (CPRs)

1. Physicians' Needs for Computer-based Patient Records 3

Clement J. McDonald

2. Clinicians' Needs for Office Computer-based Patient Records 12 Carmi Z. Margolis

3. Nurses' Needs for Computer-based Patient Records 16 Mary L. McHugh

4. Hospital Administrators' Needs for Computer-based Patient Records 30 Elaine Ullian

5. Patients' Needs for Computer-based Patient Records 36 William H. Buckley

6. The Computer-based Patient Record: The Third Party Payer's Perspective 40 Cary Sennett

7. Health Care Researchers' Needs for Computer-based Patient Records 46 Allyson Ross Davies

8. Record Administrators' Needs for Computer-based Patient Records 57 Margret K. Amatayakul and Mary Joan Wogan 


\section{Section 2 Technologies for Computer-based Patient Records} (CPRs)

1. Current State of Computer-based Patient Record Systems 67 Allan T. Pryor

2. Database Systems for Computer-based Patient Records 83 William W. Stead, Gio Wiederhold, Reed Gardner, W. Edward Hammond, and David Margolies

3. Terminals and Workstations for Computer-based Patient Records 99 J. Robert Beck, G. Octo Barnett, Paul D. Clayton, and Ifay F. Chang

4. The Health Care Professional's Workstation: Its Functional Components and User Impact 102 John S. Silva and Anthony J. Zawilski

5. Data Acquisition for the Computer-based Patient Record 125 Allan H. Levy and David P. Lawrance

6. Data Entry for Computer-based Patient Records 140 Gregory C. Critchfield

7. Information Retrieval 146 Allan H. Levy and David P. Lawrance

8. Image Processing and Storage for Computer-based Patient Records 153 John A. Norris and Jerome R. Cox

9. Data Exchange Standards for Computer-based Patient Records 157 Clement J. McDonald and George H. Hripcsak

10. The Unified Medical Language System (UMLS) and Computer-based Patient Records 165

Donald A.B. Lindberg and Betsy L. Humphreys

11. New Communication Technologies for Integrating Hospital Information Systems and Their Computer-based Patient Records 176 Helmuth F. Orthner

12. System and Data Protection 201 Gretchen Murphy

13. Medical Text Processing: Past Achievements, Future Directions 212 Carol Friedman and Stephen B. Johnson

14. Essential Technologies for Computer-based Patient Records: A Summary 229

Richard S. Dick and Elaine B. Steen 
15. The Computer-based Patient Record System Vendor Survey 262 Marion J. Ball

Section 3 The Future of the Computer-based Patient Record (CPR)

1. Future Vision and Dissemination of Computer-based Patient Records 273 Edward H. Shortliffe, Paul C. Tang, Margret K. Amatayakul, Eric Cottington, Stephen F. Jencks, Albert Martin, Robin MacDonald, Thomas Q. Morris, and Jeremy J. Nobel

2. A Bold Vision: The Computer-based Patient Record Institute 294 Richard Dick

Index 303 


\section{Contributors}

MARGRET K. AMATAYAKUL, R.R.A.

Associate Executive Director, American Medical Record Association, Chicago, IL, USA

MARION J. BALL, Ed.D.

Vice President of Information Services, University of Maryland at Baltimore, Baltimore, MD, USA

G. OCTO BARNETT, M.D.

Professor of Medicine, Harvard University, Boston, MA, USA

J. ROBERT BECK, M.D.

Professor, Department of Pathology, Oregon Health Sciences University,

Portland, OR, USA

WILLIAM H. BUCKLEY

Director of Patient Care Representatives, Massachusetts General Hospital, Boston, MA, USA

IFAY F. CHANG, Ph.D.

Manager of Application Solutions Institute, IBM T.J. Watson Research Center, Yorktown Heights, NY, USA

PAUL D. CLAYTON, Ph.D.

Professor and Director, Center for Medical Informatics, Columbia Presbyterian Medical Center, New York, NY, USA

MORRIS F. COLLEN, M.D.

Director Emeritus, Division of Research, Kaiser Permanente Medical Care Program, Oakland, CA, USA 
ERIC COTTINGTON, Ph.D.

Director of Research Support, Allegheny Singer Research, Pittsburgh, PA, USA

JEROME R. COX, Sc.D.

Welge Professor of Computer Science and Director, Applied Research Laboratory, Washington University, St. Louis, MO, USA

GREGORY C. CRITCHFIELD, M.D.

Associate Professor of Microbiology, Brigham Young University, Provo, UT, USA

ALLYSON ROSS DAVIES, Ph.D.

Director of Quality Assessment, New England Medical Center Hospitals, Boston, MA, USA

DON E. DETMER, M.D.

Vice President for Health Sciences, University of Virginia Health Sciences Center, Charlottesville, VA, USA

RICHARD S. DICK, Ph.D.

Executive Director for the Coalition for the Computer-Based Patient Record Institute, Washington, DC, USA

CAROL FRIEDMAN, Ph.D.

Assistant Professor, Computer Science, Queens College of the City University of New York, NY, USA

REED GARDNER, Ph.D.

Professor of Biophysics, University of Utah, Salt Lake City, UT, USA

W. EDWARD HAMMOND, Ph.D.

Professor, Biometry and Medical Informatics, Duke University, Durham, NC, USA

GEORGE H. HRIPCSAK, M.D.

Assistant Professor, Center for Medical Informatics, Columbia Presbyterian Medical Center, New York, NY, USA

BETSY L. HUMPHREYS, M.L.S.

Deputy Associate Director, Library Operations, National Library of Medicine, Bethesda, MD, USA

STEPHEN F. JENCKS, M.D.

Chief Scientist, Office of Research, Office of Research and Demonstrations, Health Care Financing Administration, Baltimore, MD, USA 
STEPHEN B. JOHNSON, Ph.D.

Assistant Professor, Center for Medical Informatics, Columbia University, New York, NY, USA

DAVID P. LAWRANCE, M.D.

Assistant Professor, University of Illinois, College of Medicine and Visiting Assistant Professor, National Center for Super Computing Applications, University of Illinois at Urbana-Champaign, Urbana, IL, USA

ALLAN H. LEVY, M.D.

Professor and Head, Department of Medical Information Science, University of Illinois Medical Center, Urbana, IL, USA

DONALD A.B. LINDBERG, M.D.

Director, National Library of Medicine, Bethesda, MD, USA

ROBIN MACDONALD, R.N.

Senior Consultant, Booze, Allen \& Hamilton, Inc., Bethesda, MD, USA

DAVID MARGOLIES, M.D.

Associate in Medicine, Children's Hospital, Boston, MA, USA

CARMI Z. MARGOLIS, M.D., M.A.

Hersch Professor of Community Health and Primary Care and Vice Dean for Medical Education, Ben Gurion University, Beer-Sheva, Israel

ALBERT MARTIN, M.D.

President and Chief Executive Officer, InterPractice Systems, Inc., San Francisco, CA, USA

CLEMENT J. McDONALD, M.D.

Professor of Medicine, Regenstrief Institute for Health Care, Indianapolis, IN, USA

MARY L. McHUGH, Ph.D., R.N.

Director of Nursing Research and Development, St. Francis Regional Medical Center, Wichita, KS, USA

THOMAS Q. MORRIS, M.D.

President and Chief Executive Officer, Columbia Presbyterian Hospital, New York, NY, USA

GRETCHEN MURPHY

Director of C/RIS, Group Health Cooperative of Puget Sound, Seattle, WA, USA 
xxiv

Contributors

JEREMY J. NOBEL, M.D., M.P.H.

Lecturer in Health Policy, Department of Health Policy and Management, Harvard School of Public Health, Boston, MA, USA

JOHN A. NORRIS, J.D., M.B.A.

Corporate Executive Vice President, Hill and Knowlton, Inc., Walpham, Massachusetts and Lecturer in Health Law, Harvard School of Public Health, Boston, MA, USA

HELMUTH F. ORTHNER, Ph.D.

Director of Division of Academic Computer Services, Department of Computer Services and Professor of Computer Medicine, George Washington University Medical Center, Washington, DC, USA

ALLAN T. PRYOR, Ph.D.

Professor of Medical Informatics, University of Utah, Salt Lake City, UT, USA

CARY SENNETT, M.D.

Medical Director and Director, Clinical Quality, Aetna Life Insurance Company, Hartford, CT, USA

EDWARD H. SHORTLIFFE, M.D., Ph.D.

Professor of Medicine and Computer Science, Stanford University Medical School, Stanford, CA, USA

JOHN S. SILVA, M.D.

Assistant Professor of Surgery, Department of Surgery, Uniformed Services University of the Health Sciences, USAF, Bethesda, MD, USA

WILLIAM W. STEAD, M.D.

Associate Vice Chancellor for Health Affairs and Professor of Medicine, Vanderbilt University, Nashville, TN, USA

ELAINE B. STEEN, M.A.

Assistant to the Vice President, University of Virginia, Health Sciences Center, Office of the Vice President, Charlottesville, VA, USA

PAUL C. TANG., M.D.

Program Manager, HP Laboratories, Palo Alto, CA, USA

ELAINE ULLIAN, M.P.H.

President and Chief Executive Officer, Faulkner Hospital, Boston, MA, USA 
GIO WIEDERHOLD, Ph.D.

Research Professor, Computer Science Department, Stanford University, Stanford, CA, USA

MARY JOAN WOGAN, R.R.A.

Director of the Washington Office, American Medical Record Association, Washington, DC, USA

ANTHONY J. ZAWILSKI, M.E.E.

Technical Program Manager, MITRE Institute, The MITRE Corporation, McLean, VA, USA 